\title{
The artificial kidney and urea clearance
}

\author{
D. J. BLACKMORE AND W. J. ELDER \\ From the Research Department, R.A.F. Institute of Pathology and Tropical Medicine and the Renal \\ Unit, Princess Mary's R.A.F. Hospital, Halton, Aylesbury, Bucks.
}

SYNOPSIS A theoretical efficiency has been calculated from the known urea clearance of the artificial kidney, the assumed total body water of the patient, and the initial plasma urea.

The efficiency of dialysis never significantly exceeded the calculated figure. In some patients with trauma or glomerulonephritis the efficiency was very poor whereas in patients with renal failure complicating pregnancy the actual and calculated efficiencies were very close.

These observations are discussed and possible reasons for the failure of dialysis to bring down the plasma urea to the expected concentration are suggested.

We have been struck by the variable results of dialysis assessed in terms of plasma urea fall and clinical response while using a twin-coil artificial kidney during the past three years (Jackson, Bunker, Elder, and Joekes, 1960). It has been suggested that the variability of dialysis in vivo may be due to differences in blood flow rate and coil efficiency (Travenol leaflet provided with each disposable coil and Elliott, Horn, Kerr, and Pearson, 1961). Our experience indicated that these were unlikely to be a complete explanation, especially as post-obstetric patients consistently responded well to dialysis with high plasma urea clearances whereas some glomerulonephritic and post-traumatic patients had poor clearances and improvement in their clinical state was less satisfactory.

Haemodialysis has been extensively investigated in vitro, and parameters have been deduced which allow for mathematical analysis of artificial kidney function (Wolf, Remp, Kiley, and Currie, 1951). As sufficient data are available on most of our dialyses we have accordingly analysed them with respect to urea clearance.

\section{MATERIAL AND METHODS}

Haemodialyses were performed with a Kolff disposable twin-coil unit using a modified Travenol artificial kidney. The coil was sealed in the can with sponge rubber and the bath fluid circulating pump altered to give a constant flow of 34 litres per minute under variable load. The blood flow rate was measured by electromagnetic induction (Brennand and Bunker, 1960). Sodium and potassium concentrations in the dialysing fluid varied

Received for publication 12 July 1961. from patient to patient but no urea was added. Urea was estimated on heparinized plasma by a urease-nesslerization technique (King and Wootton, 1956). High plasma ureas ( $>100 \mathrm{mg} . / 100 \mathrm{ml}$.) were diluted before estimation. All tests were performed in duplicate with adequate control of recovery and standard solutions.

Dialyses which fulfilled the following criteria were selected for inclusion in this investigation:-

1, Clinically uneventful, uninterrupted six-hour dialyses; 2 , dialysing fluid changed at two-hour intervals; 3 , blood flow rate constant $( \pm 20 \mathrm{ml}$./min.) within the range 250 to $400 \mathrm{ml}$./min.; 4, circuit outflow pressure less than $80 \mathrm{~mm}$. $\mathrm{Hg} ; 5$, patient's weight between 50 and $80 \mathrm{~kg}$; ; and 6, consistent biochemical data were available. Sixty out of 222 dialyses fulfilled these requirements.

If urea is evenly distributed and freely diffusible throughout the total body water it should be possible to calculate the expected plasma urea at the end of dialysis from the intitial plasma urea and the urea clearance of the artificial kidney. It would also be reasonable to assume that delay in intracellular fluid-extracellular fluid equilibration and the rate of urea production during dialysis would have little effect.

A nomogram (Fig. 1) was constructed to give the expected plasma urea at the end of dialysis assuming that the total body water was $57 \%$ of the body weight. The nomogram was based on the equation derived by Wolf et al. (1951) using standard nomographic technique. The following is an example of its use:

Let patient's pre-dialysis plasma urea $=400 \mathrm{mg} . \%$

Let patient's body weight $\quad=70 \mathrm{~kg}$.

Let blood flow rate during dialysis $=300 \mathrm{ml} . / \mathrm{min}$. then from nomogram

1 Setting 400 (initial urea Ao) on scale A and $70 \mathrm{~kg}$. (body weight) on scale D the expected plasma urea at 2 hours is obtained at scale $\mathrm{F}$ against the $70 \mathrm{~kg}$. line (240).

2 Repeat with Ao at 240 , then at 4 hours expected plasma urea is 145 . 

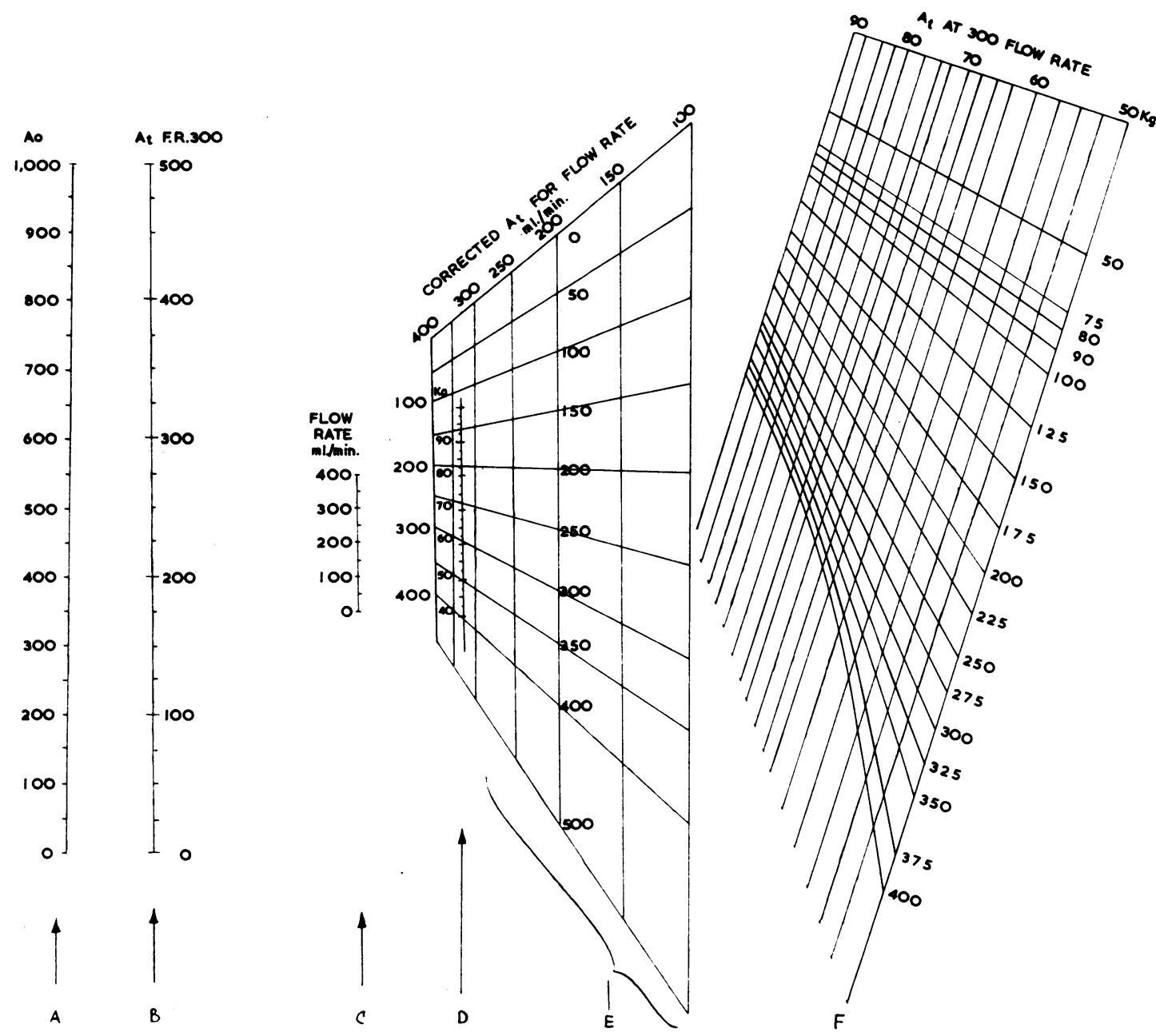

FIG. 1. Nomogram for determining expected plasma urea.

$$
\begin{aligned}
& \quad-\left[\frac{\mathrm{B}+\mathrm{V}}{\mathrm{B}} \cdot \frac{\mathrm{Ct}}{\mathrm{V}}\right] \\
& \mathrm{At}=\frac{\mathrm{B}}{\mathrm{B}+\mathrm{V}} \cdot \mathrm{A}_{\mathrm{o}} \mathrm{e}+\mathrm{A}_{\mathrm{o}} \frac{\mathrm{V}}{\mathrm{B}+\mathrm{V}} \\
& \mathrm{B}=\text { dialysing fluid volume }(\mathrm{ml} .) \\
& \mathrm{V}=\text { total body water } 4 / 7 \mathrm{~kg} .(\mathrm{ml} .)
\end{aligned}
$$

3 Repeat setting Ao at 145, then at 6 hours expected plasma urea is 90 .

Should the blood flow rate not be $300 \mathrm{ml}$./min., it is corrected at each stage utilizing scales $\mathrm{B}, \mathrm{C}$, and $\mathrm{E}$ in a similar manner.

So that comparison between dialyses would be possible a relationship between the calculated and observed postdialysis plasma urea was derived as follows:

$100\left[\frac{\mathrm{Uc}-\mathrm{Uo}}{\mathrm{Uc}}\right]=$ efficiency index

$\mathrm{Uc}=$ calculated immediate post-dialysis plasma urea

Uo $=$ observed immediate post-dialysis plasma urea $\mathrm{t}=2$ hours $(120 \mathrm{~min}$.

$\mathrm{C}=$ clearance (as found by Elliott et al., 1961)

Ao $=$ initial plasma urea $(\mathrm{mg} . / 100 \mathrm{ml}$.

At $=$ expected plasma urea $(\mathrm{mg} . / 100 \mathrm{ml}$.)

$\mathrm{e}=2 \cdot 72$

EXAMPLE Let the calculated immediate post-dialysis plasma urea (Uc) $=90 \mathrm{mg} . \%$.

Let the observed immediate post-dialysis plasma urea (Uo) $=150 \mathrm{mg} . \%$, then

$$
\text { efficiency index }=100\left[\frac{90-150}{90}\right]=-66
$$

RESULTS

When the results of the 60 dialyses were assessed in this way it was evident that there was some relation- 
TABLE I

RELATION BETWEEN CLINICAL CONDITION, EFFICIENCY INDEX, AND RATES PLASMA UREA RISE

\begin{tabular}{|c|c|c|c|c|c|c|c|}
\hline Sex Age & $\begin{array}{l}\text { No. of } \\
\text { Dialysis }\end{array}$ & $\begin{array}{l}\text { Day of } \\
\text { Oliguria }\end{array}$ & $\begin{array}{l}\text { Pre- } \\
\text { dialysis } \\
\text { Plasma } \\
\text { Urea } \\
(\mathrm{mg} . \%)\end{array}$ & $\begin{array}{l}\text { Efficiency } \\
\text { Index }\end{array}$ & $\begin{array}{l}\text { Rate of } \\
\text { Pre- } \\
\text { dialysis } \\
\text { Plasma } \\
\text { Urea } \\
\text { Rise }^{1}\end{array}$ & $\begin{array}{l}\text { Rate of } \\
\text { Post- } \\
\text { dialysis } \\
\text { Plasma } \\
\text { Urea } \\
\text { Rise }^{2}\end{array}$ & $\begin{array}{l}\text { Ratio of } \\
\text { Post- } \\
\text { to Pre- } \\
\text { dialysis } \\
\text { Rates of } \\
\text { Rise }\end{array}$ \\
\hline
\end{tabular}

Traumatic

G.H.H. Multiple injuries

12
18
26
9

$\begin{array}{lll}\text { M } & 54 & 2 \\ & & 3 \\ \text { M } & 58 & 1 \\ \text { M } & 61 & 1 \\ \text { M } & 21 & 1 \\ \text { M } & 21 & 1 \\ & & 2 \\ \text { M } & 76 & 1 \\ \text { M } & 36 & 1 \\ & & 3 \\ \text { F } & 16 & 1 \\ \text { F } & 43 & 1 \\ & & 2 \\ \text { M } & 19 & 1 \\ \text { M } & 64 & 1 \\ & & 2 \\ \text { M } & 63 & 1 \\ & & 2 \\ & & 3 \\ \text { M } & 44 & 1\end{array}$

F.L. Aortic valvotomy

C.T.H. Prostatectomy

B.J. Multiple injuries

J.W.K. Multiple injuries

A.V. Resection of carcinoma colon

R.V. Multiple injuries

H.S. Multiple injuries

D.S. Fusion cervical spine

A.D. Facial injuries

G.H. Appendicectomy

H.C.H. Partial gastrectomy

C.H.S. Partical gastrectomy

Glomerulonephritic

R.S. Chronic

P.L. Subacute

L.W.C. Chronic

J.C.M. Chronic

G.A.W. Subacute

J.L. Acute

R.N. Chronic

D.A.M. Subacute

C.T. $\quad$ Chronic

Obstetric

R.T. Accidental haemorrhage 36/52

I.J. Abortion 26/52

M.H. Septic abortion 12/52

S.S. Accidental haemorrhage 36/52

J.V. Eclampsia-stillbirth 28/52

Miscellaneous

W.H.S. Malignant hypertension

J.G. Myocardial infarction

L.S. $\quad \mathrm{Na} \mathrm{ClO}$, poisoning

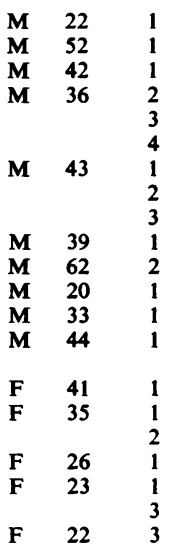

14
11
16
23
22
28
33
12
10
12
11
12
13
25
1
24
26

14
11
11
16
23
22
28
33
29
12
10
12
11
12
13
25
13
11
24
26

$\begin{array}{ll}M & 36 \\ \text { F } & 65 \\ M & 48\end{array}$

H.D. Bacillary dysentery

B.M. M.T. malaria

M 51

M 36

J.P. $\quad \mathrm{C} \mathrm{Cl}_{4}$ poisoning

B.R.. Dissecting aneurysm

$\begin{array}{ll}\mathbf{6 0 0} & - \\ \mathbf{5 0 0} & - \\ \mathbf{5 2 0} & - \\ \mathbf{3 5 0} & - \\ \mathbf{3 8 0} & - \\ \mathbf{3 5 0} & - \\ \mathbf{3 9 0} & - \\ \mathbf{4 9 0} & - \\ \mathbf{5 5 0} & - \\ \mathbf{2 5 0} & - \\ \mathbf{3 6 5} & - \\ \mathbf{5 6 0} & - \\ \mathbf{5 0 0} & - \\ \mathbf{3 7 0} & - \\ \mathbf{3 7 0} & - \\ \mathbf{3 8 0} & - \\ \mathbf{4 0 0} & - \\ \mathbf{3 9 0} & - \\ \mathbf{4 0 0} & - \\ \mathbf{5 4 0} & - \\ 335 & - \\ \mathbf{3 2 0} & - \\ \mathbf{3 1 5} & - \\ \mathbf{4 2 0} & - \\ \mathbf{4 1 0} & -\end{array}$

-55
-55
-16
-77
-52
-46
-15
-60
-34
-14
-72
-47
-43
-56
-52
-69
-108
-76
-36
-2
-56
-62
-22
-75
-93

0.19

$0 \cdot 26$

$0 \cdot 37$

$-108$

$-62$

$0 \cdot 34$

0.51

0.27

$0 \cdot 15$

0.29

0.46

0.85

0.31

0.33
0.80

0.43

$4 \cdot 3$

0.48

65

0.48

0.80

0.21

0.41

0.47

0.56
0.27

0.27
0.47

0.44

0.93

0.58

0.51

0.55
0.21

0.33

$0 \cdot 16$

0.44

0.14

0.81

$1 \cdot 2$

.94

$2 \cdot 1$
$1 \cdot 8$

$1 \cdot 5$

2.05

0.4

$2 \cdot 7$

$\begin{array}{ll}440 & -61 \\ 430 & -11 \\ 490 & -42 \\ 460 & -140 \\ 470 & -88 \\ 590 & -92 \\ 620 & -69 \\ 490 & -63 \\ 410 & -133 \\ 490 & -40 \\ 500 & -140 \\ 300 & -94 \\ 500 & -40 \\ 535 & -11 \\ & \\ 340 & -14 \\ 670 & -8 \\ 300 & +3 \\ 415 & +3 \\ 355 & -6 \\ 320 & +15 \\ 410 & -7\end{array}$

0.25

0.29

1.15

0.47

0.51

1.09

$-42$

$-88$

$-92$

$-69$

\subsection{2}

0.376

$0 \cdot 15$

0.31

0.61

0.49
0.55

0.49

0.21
0.38

0.38

0.41

0.57

0.28

0.68

0.32
0.14

$0.83 \quad 0.59$

0.71

$0 \cdot 20$

0.05

0.15

$0 \cdot 39$

0.24

$0 \cdot 27$
$0 \cdot 25$

0.34

0.34
0.26

1.1

3-76

.15

0.69

1.05

1.6
0.84

$0.31 \quad 0.26$

$1 \cdot 30$

-8
-56

0.33

0.43

0.177
0.338

0.41

0.39
0.55

0.65

$-164$

31
$-\quad 62$

0.242

$0 \cdot 29$

0.47

0.35

0.35

-27
-

22
$-\quad 22$
-50

0.33

0.30
0.61

0.42
0.40

0.40

0.63

0.465

0.5

0.39

$2 \cdot 26$

1.66

1.6

1.2
0.75

1.06

1.45

1.6

0.79

$1 \cdot 2$
0.9

$2 \cdot 7$

${ }^{1}$ Rate of plasma urea rise calculated for 48 hours pre-dialysis expressed in $\mathrm{mg} . / \mathrm{kg}$. body weight/hour.

${ }^{2}$ Rate of post-dialysis plasma urea rise calculated for $\mathbf{4 0}$ hours post-dialysis, expressed in $\mathrm{mgm} / \mathbf{k g}$. body weight/hour.

${ }^{3}$ The onset of oliguria in the glomerulonephritic group was often insidious or not accurately known, thus the figures given are approximate. 


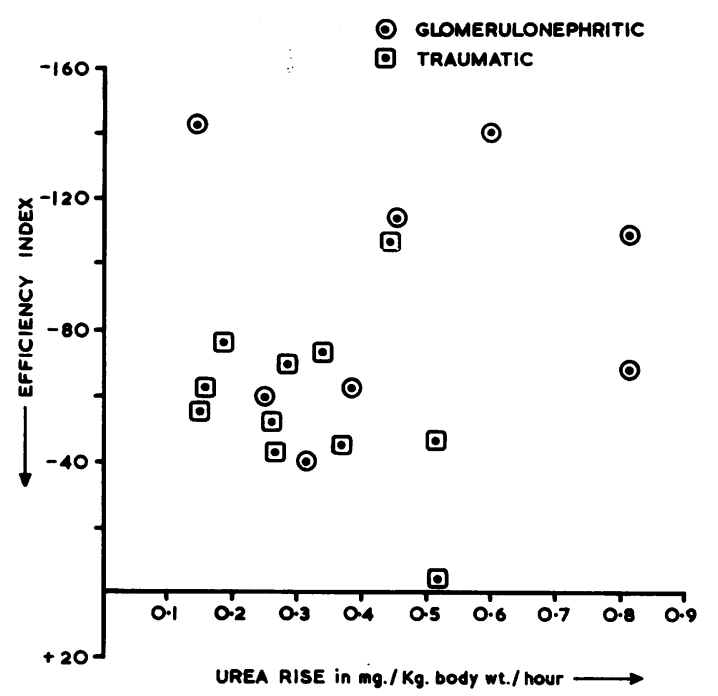

FIG. 2. Efficiency index related to pre-dialysis rate of plasma urea rise for glomerulonephritic and traumatic groups.

ship between the aetiology of the primary condition associated with the renal failure and the efficiency index of dialysis (Table I). The 25 dialyses on 13 patients with trauma had an efficiency index between -2 and -108 , and, of these, 23 dialyses had an efficiency index between -2 and -80 . The 14 dialyses on 10 patients with glomerulonephritis had an efficiency index between -40 and -140 and, of these, eight dialyses had an efficiency index between -80 and -140 . The seven dialyses on five postobstetric patients had an efficiency index between -14 and +15 . The remaining 14 dialyses on seven patients with other conditions had a wide scatter of efficiency indices from -200 to -8 .

EFFICIENCY INDEX RELATED TO PRE-DIALYSIS RATE OF PLASMA UREA RISE The efficiency index in the four groups was plotted against the pre-dialysis rate of plasma urea rise for the 48 hours before dialysis (Figs. 2 and 3).

No correlation was found and no significant difference was apparent between the groups.

EFFICIENCY INDEX RELATED TO POST-DIALYSIS RATE OF PLASMA UREA RISE The efficiency index was also plotted against the post-dialysis rate of plasma urea rise for the $\mathbf{4 0}$ hours after dialysis (Figs. 4 and 5). A significant correlation existed between the dialysis efficiency index and the post-dialysis rate of rise of urea in the traumatic and glomerulonephritic groups. There was also a statistically significant difference

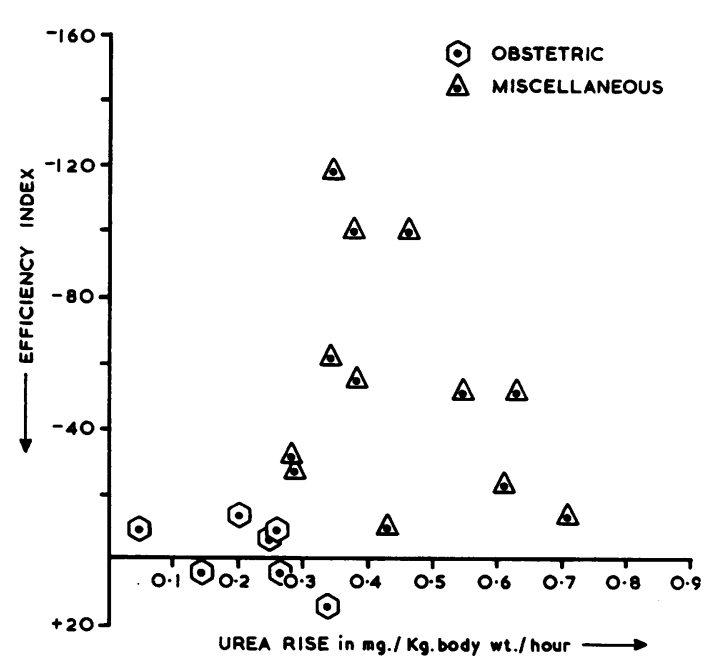

FIG. 3. Efficiency index related to pre-dialysis rate of plasma urea rise for obstetric and miscellaneous groups.

between these two groups $(\mathrm{t}=4.08$ and $\mathrm{p}<0.001)$ The difference between the obstetric patients and the other two groups was obvious.

EFFICIENCY INDEX RELATED TO RATIO POST-DIALYSIS: PRE-DIALYSIS RATES OF PLASMA UREA RISE The ratio of the post-dialysis to the pre-dialysis rate of plasma urea rise was plotted against the efficiency index in the four groups (Figs. 6 and 7). Again there was no correlation in any group between the ratio and efficiency index.

Figure 6 shows that, ignoring the efficiency index, there was a difference between the traumatic and glomerulonephritic groups in respect of the postdialysis to pre-dialysis rate of rise. It appears that traumatic patients had a significant increase in the rate of plasma urea rise after dialysis.

EFFICIENCY INDEX RELATED TO DAYS OF OLIGURIA In the traumatic and glomerulonephritic groups the $\sigma$ dialysis efficiency index was plotted against the time $N$ in days after the onset of oliguria (Figs. 8 and 9). N No obvious correlation appeared to exist between the efficiency index and days of oliguria in the glomerulonephritic or obstetric groups. In the

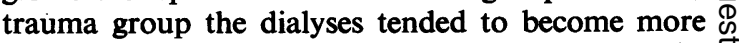
efficient with increasing length of oliguria, with the exception of one patient (H.C.H., Table I) dialysed on the thirty-sixth day from onset of renal failure, $\vec{D}$

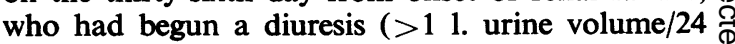
hours) four days before. It is difficult to decide 


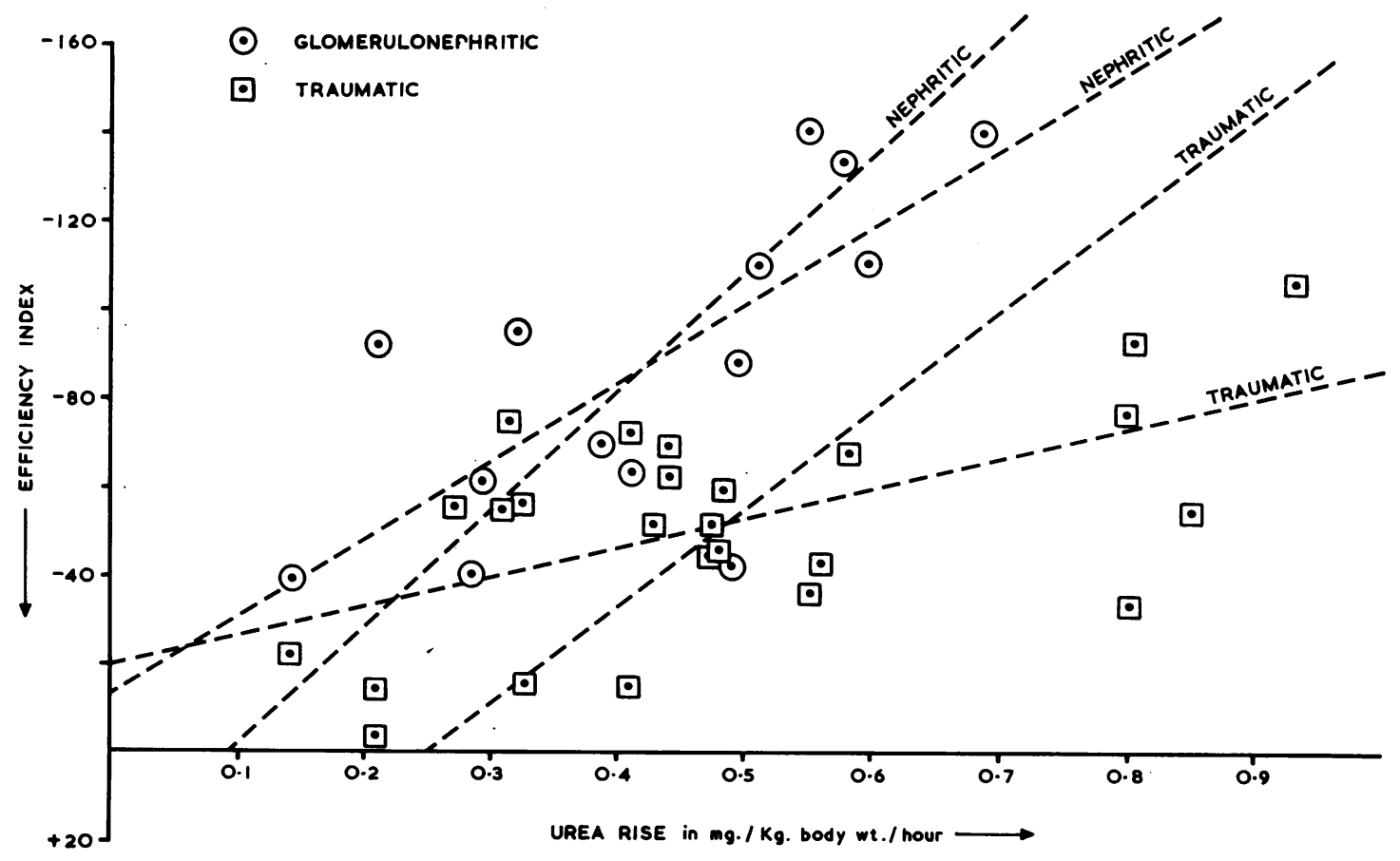

FIG. 4. Efficiency index related to post-dialysis rate of plasma urea rise for glomerulonephritic and traumatic groups. For glomerulonephritic, $r=0 \cdot 72$, and for traumatic, $r=0.54$.

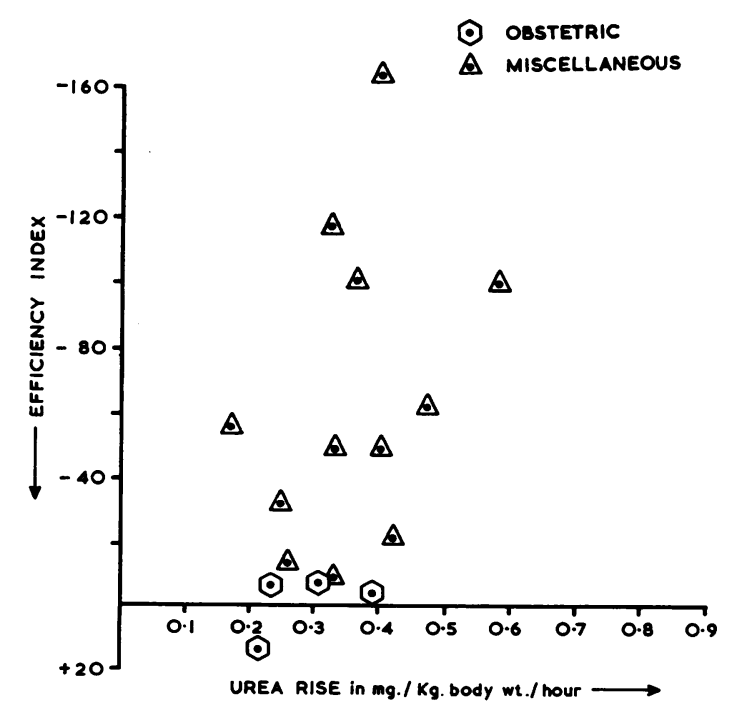

FIG. 5. Efficiency index related to post-dialysis rate of plasma urea rise for obstetric and miscellaneous groups.

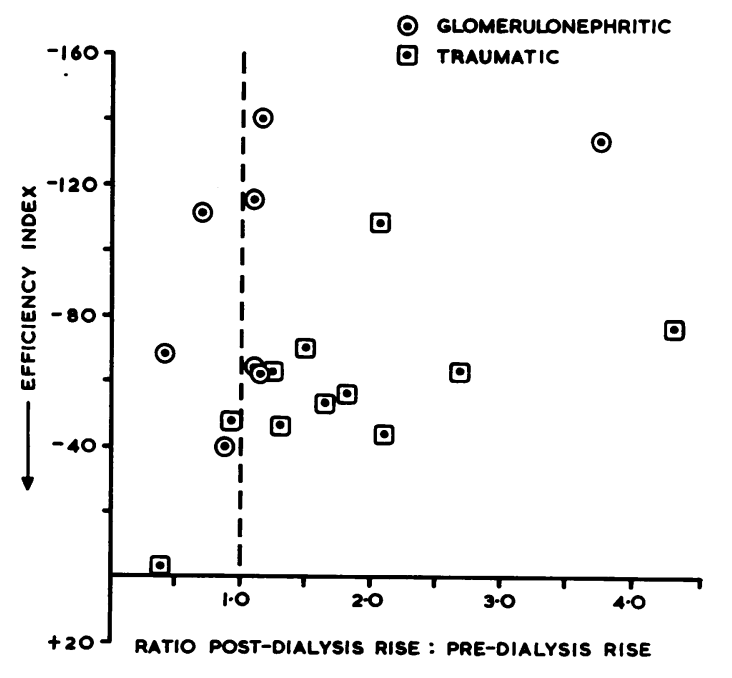

FIG. 6. Efficiency index related to the ratio post-dialysis: pre-dialysis rate of plasma urea rise for glomerulonephritic and traumatic groups. 
FIG. 7. Efficiency index related to the ratio post-dialysis: pre-dialysis rate of plasma urea rise for obstetric and miscellaneous groups.

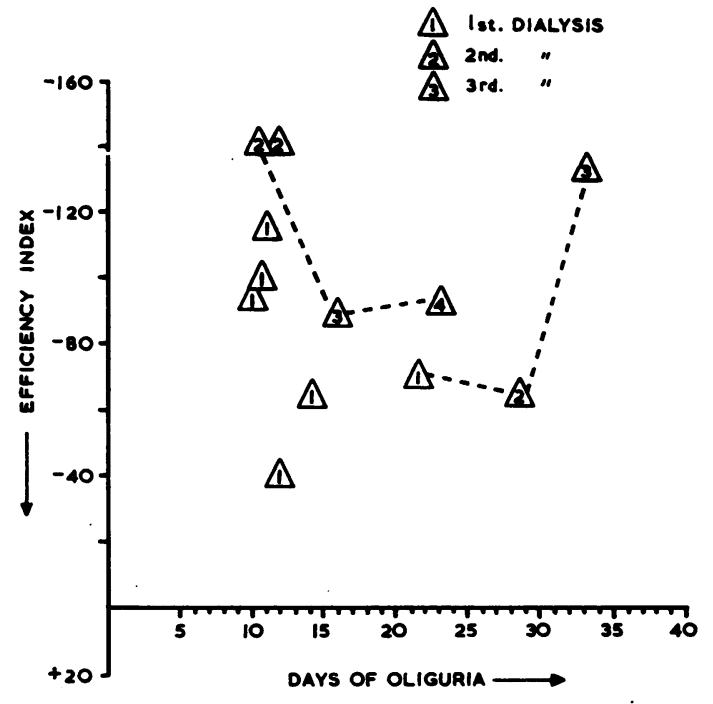

FIG. 9. Efficiency index related to days of oliguria in the glomerulonephritic group. The dotted line indicates series dialyses on the same patient.

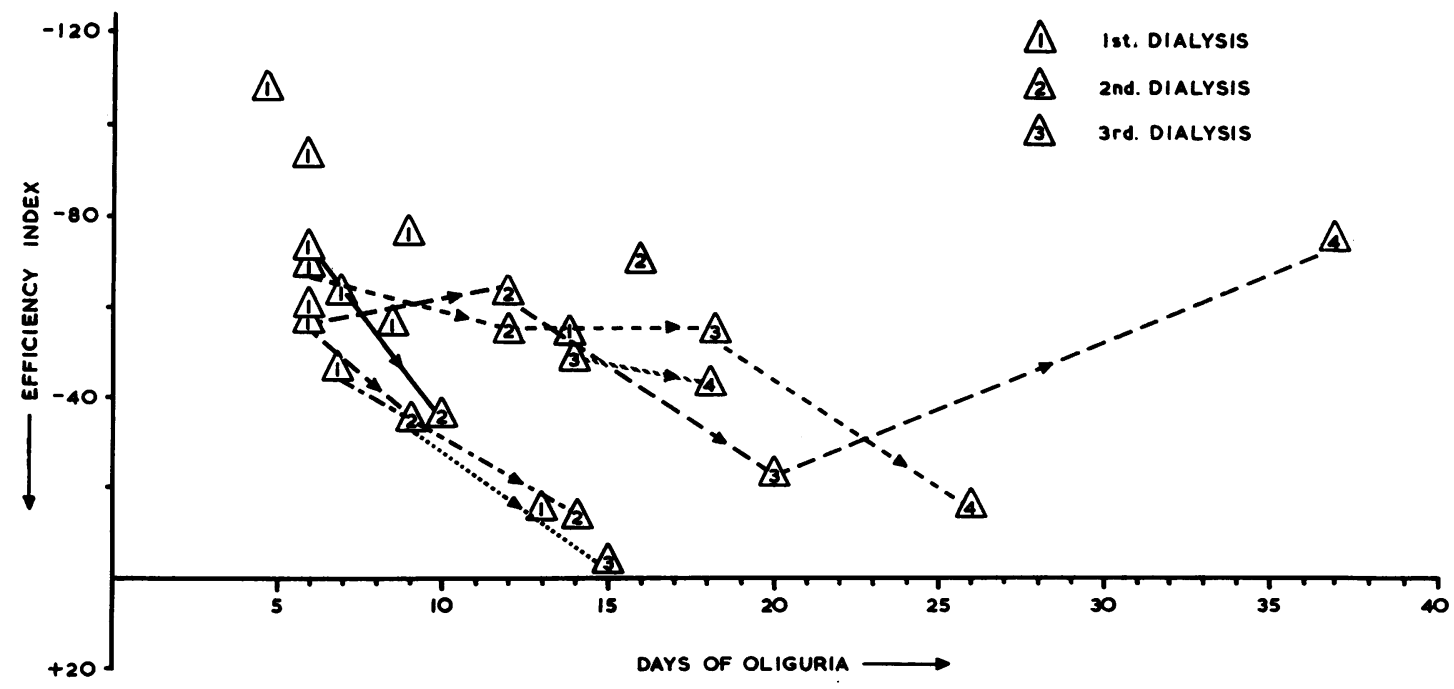

FIG. 8. Efficiency index related to days of oliguria in the traumatic group. The dotted line indicates series dialyses on the same patient. 
TABLE II

PREDICTED AND OBSERVED UREA REMOVED AT DIALYSIS

\begin{tabular}{|c|c|c|c|c|c|}
\hline & & $\begin{array}{l}\text { No. of } \\
\text { Dialysis }\end{array}$ & $\begin{array}{l}\text { Theoretical } \\
\text { Urea } \\
\text { Removed (g.) }\end{array}$ & $\begin{array}{l}\text { Actual } \\
\text { Urea } \\
\text { Removed (g.) }\end{array}$ & $\begin{array}{l}\text { Actual:Theoretical } \\
\text { Urea } \\
\text { Removed (g.) }\end{array}$ \\
\hline \multicolumn{6}{|l|}{ Traumatic } \\
\hline S.H. & Multiple injuries & $\begin{array}{l}1 \\
2 \\
3\end{array}$ & $\begin{array}{r}110 \\
119 \\
87\end{array}$ & $\begin{array}{r}101 \\
69 \\
109\end{array}$ & $\begin{array}{l}0.92 \\
0.58 \\
1 \cdot 25\end{array}$ \\
\hline C.T.H. ${ }^{1}$ & Prostatectomy & 1 & $60 \cdot 5$ & 88.6 & 1.46 \\
\hline J.N. & Multiple injuries & $\begin{array}{l}1 \\
2\end{array}$ & $\begin{array}{l}70.5 \\
68.5\end{array}$ & $\begin{array}{r}101 \cdot 1 \\
65 \cdot 1\end{array}$ & $\begin{array}{l}1.43 \\
0.95\end{array}$ \\
\hline B.J. ${ }^{1}$ & Multiple injuries & $\begin{array}{l}1 \\
2\end{array}$ & $\begin{array}{l}104 \\
114\end{array}$ & $\begin{array}{r}112 \cdot 2 \\
73 \cdot 3\end{array}$ & $\begin{array}{l}1.08 \\
0.64\end{array}$ \\
\hline J.W.K. ${ }^{1}$ & Multiple injuries & 1 & $\begin{array}{r}87 \\
140\end{array}$ & $\begin{array}{l}130 \\
135 \cdot 7\end{array}$ & $\begin{array}{l}1.49 \\
0.97\end{array}$ \\
\hline \multicolumn{6}{|c|}{ Glomerulonephritic } \\
\hline J.E.H. & Acute & 1 & $86 \cdot 2$ & 46 & 0.53 \\
\hline W.B. & Chronic & $\begin{array}{l}1 \\
2\end{array}$ & $\begin{array}{l}92 \\
96.6\end{array}$ & $\begin{array}{l}80 \\
82\end{array}$ & $\begin{array}{l}0.87 \\
0.85\end{array}$ \\
\hline V.C. & Chronic & 1 & 90.4 & 120 & $1 \cdot 33$ \\
\hline R.N. ${ }^{1}$ & Chronic & 1 & 110 & $135 \cdot 6$ & $1 \cdot 23$ \\
\hline W.w. & Acute & 1 & 233 & $179 \cdot 4$ & 0.77 \\
\hline C.C. & Chronic & 1 & $39 \cdot 2$ & $43 \cdot 75$ & $1 \cdot 15$ \\
\hline \multicolumn{6}{|l|}{ Obstetric } \\
\hline $\begin{array}{l}\text { I.J. } \\
\text { J.S. }\end{array}$ & $\begin{array}{l}\text { Abortion } 26 / 52 \\
\text { Post-partum haemorrhage }\end{array}$ & $\begin{array}{l}1 \\
1\end{array}$ & $\begin{array}{l}76 \\
93 \cdot 2\end{array}$ & $\begin{array}{l}84 \cdot 6 \\
81\end{array}$ & $\begin{array}{l}1 \cdot 1 \\
0.86\end{array}$ \\
\hline
\end{tabular}

The theoretical urea removal was calculated from the plasma urea fall observed across dialysis assuming that the total body water was $57 \%$ of the body weight.

${ }^{1}$ The dialyses of these patients are also included in Table $\mathbf{I}$.

whether the improving plasma urea clearance was a function of time or whether it was related to previous dialyses.

PREDICTED AND OBSERVED UREA REMOVED BY DIALYSIS Unfortunately an accurate estimate of the total amount of urea removed by dialysis is only available in 19 dialyses (Table II), and only five of these patients could be included in the present paper. In general the results are equivocal, but in the traumatic group the urea removed during the second dialysis was less than that removed by the first dialysis.

\section{DISCUSSION}

It is of interest that only those patients with acute renal failure complicating pregnancy behave in the predicted manner with respect to urea clearance. Also it appears from only two estimations of urea removal by dialysis (Table II) that they lose their urea to the dialysing fluid in a similarly predictable way.

We have found that patients with acute renal failure complicating trauma have a poor plasma urea clearance on their first dialysis with the predicted or more than the predicted amount of urea removed and an improved clearance with a lower urea removal in subsequent dialyses. They also showed a significantly greater post-dialysis rate of plasma urea rise than the pre-dialysis rise and the less efficient their dialyses the greater was the postdialysis rate of plasma urea rise.

The least efficient plasma urea clearance in this series was found in patients with glomerulonephritis. Those patients with renal failure of aetiology other than the three groups mentioned presented a wide range of results, the majority of which deviated from the predicted figures.

In trying to interpret these anomalous findings the postulate made by Merrill (Merrill quoted by Mather, 1960) that, in some patients, dialysis releases a metabolic block to the production of urea should be considered. If this is to account for the variation in plasma urea clearance enormous quantities of urea would have to be produced during dialysis to affect materially the calculated result. The rate of urea production in the body of a normal man weighing $70 \mathrm{~kg}$. is of the order of $1 \mathrm{~g}$. per hour; the production of $6 \mathrm{~g}$. of urea in as many hours would only increase the blood urea by $15 \mathrm{mg}$. $/ 100 \mathrm{ml}$. A urea production as high as three times normal could not significantly affect the efficiency index. Also, it might be expected that the post-dialysis rate of plasma urea rise would be much greater than the pre-dialysis rate. Although this was seen in the traumatic group (see Fig. 6) it was 
not found in most of the glomerulonephritic group where an efficiency index of between -80 and -140 was common. In the latter group it was also observed, with only one exception, that the calculated urea removal by dialysis approximated the actual removal.

Another possible explanation is that urea exists both in cell and plasma in diffusible and nondiffusible forms and that there is a greater ratio of non-diffusible to diffusible urea in the cell than in the plasma, these levels being maintained in equilibrium. The ratio might be determined by the aetiology of the primary condition.

Therefore on dialysis the following observations would be made: 1 An increased ratio of nondiffusible to diffusible plasma or cell urea would lower the efficiency index. 2 In the traumatic group an increased ratio of non-diffusible to diffusible cell urea before dialysis might result in a higher cell than plasma total urea concentration. If this is so the total body urea concentration would be higher than that calculated from the plasma urea level. Therefore more urea could pass into the dialysing fluid than predicted from the plasma urea drop. Thus it is not necessary to postulate the release of a metabolic block to the production of urea to account for the excess urea in the bath. During dialysis the equilibrium would be disturbed and a subsequent dialysis following re-establishment of an equilibrium at a lower non-diffusible level would result in a better efficiency index with a lower recovery of urea from the bath than was found formerly. 3 In the glomerulonephritic group a greater ratio of non-diffusible to diffusible plasma urea but a lower ratio of nondiffusible to diffusible cell urea than in the traumatic group might result in a lower efficiency index, with an approximate theoretical urea recovery from the bath and a lower post-dialysis rise in plasma urea.

\section{CONCLUSION}

We conclude from our results that it is difficult to accept urea as a freely diffusible, rapidly equilibrating substance in all patients. Only in the obstetric group does this assumption appear to allow accurate prediction of dialysis results.

The results from our other groups suggest that in some circumstances this is not wholly true and that urea might exist in both diffusible and non-diffusible forms. We already have some experimental evidence supporting this thesis but so far too few cases to justify any firm conclusion but we hope that publication at this stage might interest other units working in this field.

Following the preparation of this paper for publication Murdaugh and Doyle (1961) have reported the binding of urea by haemoglobin and albumin. They also showed that the quantity of urea bound was related to the urea concentration, indicating that the urea-binding ratios of haemoglobin and albumin will not become saturated in the range 10 to $400 \mathrm{mg}$. urea $/ 100 \mathrm{ml}$. These authors also report that others have suggested that protein will bind urea. Ralls (1943) showed that urea was not equally distributed between red cell water and plasma water and found an average distribution of $1.14: 1.00$. ज Pasynskii and Chernyak (1950) reported that the 을 adsorption of urea on albumin and globulin was not related to their respective water content and $c$ ) suggested that on a molar basis one urea unit will bind with two amino-acid residues.

We feel therefore that it is possible that protein binding of urea could be an explanation of its apparent non-diffusibility. It is also possible that a $\vec{\bullet}$

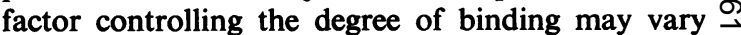
with the aetiology of the primary condition preceding renal failure.

We wish to thank the Director General of Medical Services of the Royal Air Force for permission to publish, Air Commodores W. P. Stamm and R. C. Jackson for their encouragement, Dr. A. M. Joekes for his advice, $\overline{\bar{O}}$ and Dr. C. H. Bowden for his assistance in the interpretation of the findings.

\section{REFERENCES}

Brennand, R., and Bunker, N. V. (1960). Lancet, 1, 578. Elliott, W., Horn, D. B., Kerr, D. N. S., and Pearson, D. T. (1961). Ibid, 1, 248.

Jackson, R. C., Bunker, N. V. D., Elder, W. J., and Joekes, A. M. (1960). Brit. med. J., 2, 1909.

King, E. J., and Wootton, I. D. P. (1956). Micro-analysis in Medical 음 Biochemistry, 3rd ed., p. 14. Churchill, London.

Merrill, J. P. (Quoted by Mather, J., 1960). Trans. Amer. Soc. artif. $\frac{D}{O}$ intern. Org., 6, 83.

Murdaugh, H. V., and Doyle, E. M. (1961). J. Lab. clin. Med., 57, 759.

Pasynskii, A. G., and Chernyak, R.S. (1950). C.R. Acad. Sci. U.S.S.R., 73, 771. (Chem. Abst. (1951) 45, 685).

Ralls, J. O. (1943). J. biol. Chem., 151, 529.

Wolf, A. V. Remp. D. G., Kiley, J. E, and Currie, G. D. (1951). J. W clin. Invest., 30, 1062. 